\title{
Sectoral Restructuring and Labor Mobility: A Comparative Look at the Czech Republic
}

\author{
By: Vit Sorm and Katherine Terrell
}

Working Paper Number 273

November 1999 


\title{
SECTORAL RESTRUCTURING AND LABOR MOBILITY: A COMPARATIVE LOOK AT THE CZECH REPUBLIC ${ }^{1}$
}

\author{
Vit Sorm \\ The William Davidson Institute \\ University of Michigan Business School, Ann Arbor \\ and CERGE-EI, Prague \\ SORM@UMICH.EDU \\ and \\ Katherine Terrell \\ The William Davidson Institute \\ University of Michigan Business School, Ann Arbor \\ TERRELL@UMICH.EDU \\ 701 Tappan Street \\ Ann Arbor, Michigan 48109-1234 USA \\ Last Revised \\ November 15, 1999
}

\footnotetext{
${ }^{1}$ The authors are grateful for the support from National Council for Soviet and East European Research (contract no. 810-22) and the National Science Foundation (Grant No SBR-951-2001). The paper benefited from suggestions by the participants of the 1997 Labor Workshop at the Central European University, Budapest and the 1998 Comparative Economics Seminar at the University of Michigan, Ann Arbor. We thank Randall Filer, Roger Gordon, Stepan Jurajda, Hartmut Lehmann, Jan Kmenta, Janos Kollo, Jan Svejnar, and two anonymous referees for their comments.
} 


\begin{abstract}
Labor mobility is crucial for an efficient allocation of resources and the transition economies are often viewed as suffering from inadequate reallocation of labor. Using quarterly micro data for the 1994-1998 period, we provide a comparative analysis of the extent and determinants of labor mobility in the Czech Republic. We show there has been significant movement into the finance, trade, and tourism sectors and out of the agricultural and industrial sectors. Over half of the people who change jobs have changed sector of employment, and this restructuring has been carried out relatively efficiently in that it occurred with lower incidence and duration of unemployment than in the other transition economies. The demographic characteristics of different patterns of mobility are similar across these transition economies: we identify younger people in general and single men as individuals who more likely to change jobs or become unemployed. The more educated are experiencing more job stability and are more likely to be hired if unemployed or out of the labor force. Finally, we find in the Czech Republic, the flows between employment and unemployment are very responsive to demand conditions. Hence, we conclude that the Czech labor market is demonstrating flexibility and efficiency in the transition.
\end{abstract}

Journal of Economic Literature Classification Numbers: C41, H53, J23. 


\section{Non-Technical Summary}

In this paper we provide a comparative analysis of the extent and determinants of labor mobility in one of the more mature transition economies. Our analysis is motivated by the fact that (a) labor mobility is crucial for an efficient allocation of resources in market economies and (b) the transition economies are often viewed as suffering from inadequate reallocation of labor. We analyze worker mobility during 1994-1998 in the Czech Republic, and to the extent possible, we compare our findings to those from recent or ongoing studies of the other transition economies.

Our analysis proceeds at two levels. We first calculate gross probabilities of mobility and then estimate hazard functions with the micro data. In assessing the functioning of the transitional labor market, we focus on three characteristics: i) how much restructuring has occurred in terms of sectoral shifts; ii) to what extent has the sectoral adjustment been carried out efficiently (i.e., with job-to-job rather than jobunemployment-job flows and with relatively short rather than long spells of unemployment); iii) Which demographic groups are driving the adjustment process? iv) How do demand conditions influence mobility across these states?

We find there has been a significant shift in the structure of employment by industrial sector. The largest declines in employment were in the two largest sectors: agriculture and industry. The sectors creating employment most rapidly were the ones that had not been considered important under communism: financial services, trade, and hotels and restaurants.

We show that the changes in the employment structure were brought about relatively efficiently: generally with shorter spells of unemployment compared to the other transitional economies and relying increasingly on job-to-job mobility.

About one half of the people who change jobs (with or without a spell of joblessness) also change their sector of employment. The change in sector is occurring more among people who find a job out of unemployment or out-of-the labor force than among the job-to-job movers.

The hazard analysis indicates that people with jobs in declining sectors experience systematically different flows than people with jobs in growing sectors. Those who work in agriculture or industry are more likely to leave the labor force from a job or unemployment and less likely to find a job (in any sector) once unemployed or out of the labor force. On the other hand, individuals with jobs in growing sectors are not more likely than those with jobs in declining sectors to stay employed. They are, however, more likely to become unemployed, although they do leave unemployment for a job more rapidly than individuals who previously held jobs in either declining sector.

The hazard analysis also enables us to answer the questions about who, in terms of demographic characteristics, is more likely to leave employment, change jobs, exit unemployment etc. We find that younger people seem to be experiencing the most mobility: younger people are more likely to change jobs; they are more likely to lose their job and become unemployed although they are less likely to leave a job to go (be pushed) out of the labor force. Once unemployed, the younger are more likely to find a job and less likely to leave the labor force. Once out of the labor force, the younger are more 
likely to find a job or be seeking work (become unemployed). People with less education do not fare as well as those with more education. The less educated are less likely to stay employed, more likely to change jobs, but more likely to loose their job to unemployment or out-of the labor force and more likely to stay unemployed or out-of-the labor force. In terms of gender and marital status, we find that married men are most likely to keep their jobs (although the differences in the probabilities are small), single men are most likely to change jobs (with women's probabilities about one half of theirs). However, single men are also most likely to become unemployed. Married men are most likely to leave unemployment for a job. Men are more likely to enter/return to the labor force than women.

The labor market has been responsiveness to changes in demand conditions both at the local and national level. We estimated an elasticity of 0.11 for the job-to-job $\left(P_{e e j}\right)$ hazard with respect to a change in the local vacancy rate. The probability that an employed person became unemployed $\left(P_{e u}\right)$ declined by 0.23 percent with a one percent increase in the local vacancy rate. The probability that an unemployed person found a job $\left(P_{u e}\right)$ increased by 0.35 for a one percent increase in the local vacancy rate. None of the other hazard rates (to and from out-of-the labor force) were affected significantly by the local demand conditions. However, all were affected by changes in national conditions, as estimated with annual dummies. For example, we find that the $P_{e e j}$ rose rapidly from 1994 to 1996 and then began to decline in 1997 and again in 1998 as GDP growth declined in those two years. Similarly, the $P_{u e}$ 's declined as the economy worsened and were much lower in 1998 than in 1994, indicating that the duration of unemployment spells began to grow in that year. Conversely, the $P_{e u}$ 's were 20-30 percent lower in 1995 and 1996 than in 1997 and 1998.

We conclude that there has been a significant amount of restructuring and this restructuring has been done at a relatively low cost in that the incidence and duration of unemployment is low relative to the labor markets in other transition countries. We show that single men with less human capital are more likely to be involved in the restructuring process through their higher mobility from job-to-job and from jobs to unemployment. We hence conclude that the Czech labor market has demonstrated flexibility and efficiency in the process of transition. 


\section{Introduction}

In this paper we provide a comparative analysis of the extent and determinants of labor mobility in one of the more mature transition economies. ${ }^{1}$ Our analysis is motivated by the fact that (a) labor mobility is crucial for an efficient allocation of resources in market economies and (b) the transition economies are often viewed as suffering from inadequate reallocation of labor as a result of factors such as an undeveloped housing market, inadequate restructuring of firms and limited transportation infrastructure. We analyze worker mobility during 1994-1998 in the Czech Republic, a country that underwent one of the most thorough economic and political transformations among the Central and East European (CEE) countries. To the extent possible, we compare our findings to those from recent or ongoing studies of the other transition economies.

Our analysis proceeds at two levels. We examine labor mobility across the three fundamental labor market states (employment, unemployment and out-of-the-labor force) as well as mobility to and from jobs across the principal sectors of the economy. We quantify the magnitudes of these flows over time to assess the extent to which workers are being reallocated across the industrial sectors and the efficiency of this reallocation, defined as the ability to minimize joblessness in the process. In the sectoral analysis, we examine the extent to which workers are moving out of sectors that were traditional under central planning and into the sectors needed by the market economy. Given the availability of rich micro data, we are also able to analyze the determinants of these transitions across labor market states. For example, we identify which groups are at greater risk of becoming unemployed or have a higher probability of finding a job defined 
by both their demographic characteristics and local demand factors. We can also examine the extent to which certain industrial sectors are pushing/pulling individuals out of/into jobs, once the demographic composition and demand conditions are held constant.

In synthesizing the two prongs of our analysis, we provide evidence on labor market adjustment by examining the extent, direction and determinants of mobility across the three labor market states. We answer questions such as: i) How much restructuring has occurred in terms of sectoral shifts and which sectors have had higher mobility? ii) To what extent has the adjustment been carried out at least cost in terms of incidence and duration of unemployment? iii) Which demographic groups are driving the adjustment process? iv) How do demand conditions influence mobility across these states?

We use micro-data from Labor Force Surveys (LFS) for 1994-1998. Previous research on flows in the Czech Republic was only carried out on flows in and out of unemployment using either grouped or individual data from the administrative records of the District Labor Offices (e.g., Boeri, 1995 and Ham, Svejnar, and Terrell, 1998,1999). Except for a parallel study by Stefanova and Terrell (1998), there is no research in the Czech Republic that includes flows in or out of the other two labor market states: employment and out-of-the labor force. With the recently available micro data from the $L F S$, we are able to construct panel data for large numbers of individuals to calculate transition probabilities for narrowly defined groups. Since comparable surveys are being administered in other transition economies (e.g., Bulagria, Hungary, former East Germany, Poland, Russia, Slovakia) the resulting literature will make it possible to compare the Czech transition probabilities with those of other CEE countries. In this paper, we present the first relevant comparisons. 


\section{Overview of the Economy and Sectoral Restructuring}

The Czech economy experienced one of the more rapid transitions to a market economy in the CEE. Between 1990 and 1993, the Czechs liberalized nearly all prices, ${ }^{2}$ privatized much of the economy and opened the country to world trade while maintaining a relatively balanced budget and low inflation. Information on changes in employment by enterprise ownership indicate that privatization occurred rapidly: the employment share of the private sector, only 1 percent in 1989, grew to 47 percent by the end of 1993 and a full 63 percent by the end of $1997 .{ }^{3}$

Although the transition in the Czech Republic has been considered exceptional, it was not costless. From 1989 to 1993, GDP declined by more than one-fifth and employment fell by about one-tenth. There was a turn around during the 1994-96 period, when GDP grew at a 3-6 percent rate. However, in 1997 the economy began to slow down and GDP grew by only 1 percent. In 1998 output actually declined by an estimated 2.7 percent and the unemployment rate rose to 7 percent, while inflation stood at 10.4 percent. ${ }^{4}$

During the 1990s, the labor market has shown a tremendous amount of restructuring in terms of employment by industrial sector. As may be seen in Table 1, there were very large shifts over the 1989-1998 period, with most changes having been undertaken in the first half of the period. The largest decrease in employment was in the primary sector (agriculture, hunting and forestry) which was halved between 1989 and 1993 and reduced by an additional 29 percent between 1993 and 1998. Industry (manufacturing plus utilities) shed about one-fifth of its labor by 1993 and another 10 percent between 1993 and 1998. By comparison, the net decline in the stock of 
employment (jobs) in these sectors over a similar period, 1994 to 1997, were much smaller in Bulgaria, Estonia, Poland and Romania. Specifically, the percentage declines in the agriculture (excluding mining) and manufacturing were, respectively: -10.6 and 3.2 in Bulgaria, -1.5 and -2.9 in Estonia, -6.7 and -1.7 in Poland, and -9.3 and -5.1 in Romania (Faggio and Konings, 1999).

As might be predicted, four of the fastest growing sectors in the Czech Republic were ones that were relatively small during socialism and necessary in an open market economy: construction, wholesale and retail trade, hotels and restaurants, and financial services (see Table 1). Since these categories differ for the four other transition countries for which Faggio and Konings (1999) provide data, we cannot make direct comparisons, except to note that the trade sector did not create net employment in any of these countries, except in Estonia. There employment grew by 13.1 percent, which was less than in the Czech Republic.

[Table 1 about here]

Hence, the data on changes in the stocks of employed by industrial sector and firm ownership suggest that there was significant adjustment in the Czech economy, especially when compared with some other transitional economies. We presently examine the labor market flows associated with this restructuring. We are interested in learning the extent to which these adjustments were made at a relatively low cost in the sense that people move directly from one job to another job with no unemployment spells vs. at the relatively higher cost of moving through unemployment. We also assess which demographic groups were more involved in the adjustment in that they were more likely than others to change jobs or to be kept out of the labor market. 


\section{Data and Methodology}

The data we use are from the Labor Force Surveys (LFS) and cover approximately $1 \%$ of the households in the Czech Republic (e.g., about 28,000 households in 1995). They have been administered at quarterly intervals since the spring of $1993 .{ }^{5}$ Since two-fifths of the total sample of households are interviewed at threemonth intervals over the course of a year, it is possible to construct quarterly panel data for individuals in approximately 11,000 households. ${ }^{6}$

For the present analysis we have constructed five separate panels for the cohorts of working age individuals that entered the LFS samples in the first quarters of 1994, $1995,1996,1997$ or 1998 . We identify which of the three labor market states -employment (E), unemployment $(\mathrm{U})$ or out-of the labor force $(\mathrm{O})$-- an individual is in. The labor market state is defined by answers to questions that are worded according to the International Labor Office (ILO) guidelines. To be unemployed the person has to be: a) not working in any permanent job during the two weeks prior to the survey week and b) both seeking work and ready to take a job within the next fourteen days. A person is employed if he/she is working in a paying activity (or, following Czech norms, is on a maternity leave) during the two weeks prior to the survey. The remainder of the working age population is considered to be out-of-the labor force.

There are nine potential transitions across labor market states as represented by the following P matrix

$$
P=\left[\begin{array}{lll}
P_{e е} & P_{е и} & P_{e o} \\
P_{u е} & P_{u и} & P_{u o} \\
P_{o е} & P_{о и} & P_{o o}
\end{array}\right]
$$


where the first subscript denotes the state of origin and the second the destination. For example, $P_{o e}$ represents the probability that an individual is observed being employed at time $t$, conditional upon being out-of-the labor force at time $t$-1. $P_{u u}$ and $P_{e e}$ represent, respectively, the probability of staying unemployed and employed from one period to the next. A subgroup of individuals who stay employed from $t-1$ to $t$ may stay with the same job (defined by employer), which we denote $\mathrm{P}_{\text {ees }}$. The remainder change jobs/employers without passing through a state of joblessness; we denote this probability as $P_{e e j .}{ }^{7}$

Assuming that the probability of transition between labor market states depends only on the state currently occupied, the gross probability of transition from state $i$ to state $j$ is given by:

$$
P_{i j}=\frac{F_{i j}}{S_{i}}, i, j=e, u, o,
$$

where $F_{i j}$ is the number of individuals in state $i$ at time $t$ which flow to state $j$ at time $t+1$ and $S_{i}$ is the stock at origin. ${ }^{8}$ In this analysis, $S_{i}$ is the stock in the first quarter of each year and $F_{i j}$ refers to flows from the first quarter to the last quarter of each year (comparing two points in time); hence ignoring any flows to another state in the interim (i.e., multiple moves). ${ }^{9}$

In addition to presenting gross probabilities (equation (2)), we also estimate the determinants of individual transitions using a duration (hazard) model. The probability distribution of durations (a random variable $T$ ) can be specified by the distribution function $F(t)=\operatorname{Pr}(T \leq t)$. Some of the individuals observations may be right censored, so the probability that someone's spell lasts longer than $t$ months is given by the survivor 
function $S(t)=1-F(t)$. Conversely, the probability that a spell ends in $t$ months is given by the density function $f(t)=d F(t) / d t$. The hazard function (i.e., the probability that someone exits a state for another state at time $t$, conditional on the spell lasting until time $t$ ) is then the ratio of these two functions, $\lambda(t)=f(t) / S(t)$. The duration distribution can also be formulated in discrete time, where the integrated hazard is approximated by the sum of the conditional probabilities of leaving the state at time $t$. Hence, using the logistic function, we estimate a quarterly hazard that can be expressed as: ${ }^{10}$

$$
\lambda_{i j}(Z(t), t)=\left(1+\exp \left[-h_{i j}(t)+B_{i j}^{\prime} Z(t)\right]\right)^{-1},
$$

where $i$ is the origin state and $j$ is the destination state, $h(t)$ is the duration dependence function. Given the nature of the data these spells are left-censored, so we condition on the time that elapsed since the beginning of the spell until the time of observation by entering the duration in months. ${ }^{11}$ (However, the hazard is estimated quarterly. Each individual has from one to three quarterly-transition observations, depending on how long he/she remains in the origin state.) Finally, $Z$ is a vector of variables describing the individual's demographic characteristics, job characteristics, and quarterly demand conditions in the district where the person is residing. Since the data are pooled across the five-year period, annual dummies are used to capture overall changes in the market at the national level (demand shocks). 


\section{Empirical Findings}

\subsection{Gross Transitions across the Three Labor Market States}

In Table 2 we present an overview of the amount of mobility across these three labor market states in the Czech Republic, the transitional countries for which we have data and for the US, which is considered to have a highly mobile labor market. The gross transition probabilities are for a one-year period, except those for Bulgaria, which are based on a nine-month interval. We have painstakingly gathered these probabilities from as many countries as possible in order to compare a) the relative amount of mobility in the Czech Republic vis a vis the other transition economies and b) the extent to which the adjustment was made at least cost, in terms of incidence and duration of unemployment.

Table 2 reveals several interesting patterns in the dynamics of the Czech labor market and the other transitional economies. First, it is clear that mobility from employment to either unemployment or out-of-the labor force is relatively low in the Czech Republic. In other words, the probability that an individual stays employed from the beginning to the end of the year $\left(P_{e e}\right)$ is much higher in the Czech Republic (between 0.96 and 0.97 ) than in any of these other transition countries (between 0.84 and 0.93 ) or in the US (0.92). ${ }^{12}$ This is consistent with the finding in Table 1 that between the beginning of 1993 and the end of 1997 there was only a 1.3 percent decline in employment in the Czech Republic.

[Table 2 about here]

Does this imply that firms in the Czech Republic have not been shedding redundant labor? Many observers have criticized the Czech government for allowing 
enterprises to operate without the necessary restructuring by allowing banks to roll over bad debt. A counter argument advanced is that not as much labor shedding was needed in the Czech Republic, as for instance in Hungary, since real wages declined much more in the Czech Republic than elsewhere. Econometric evidence by Basu, Estrin and Svejnar (1999) supports the latter view. They find that by the early 1990s, firms in all the CEE economies had high employment elasticities with respect to output and wages. Hence, they were adjusting. ${ }^{13}$ But, because real wages fell more relative to output in the Czech Republic than elsewhere, the decline in employment in the Czech Republic did not need to be as great as in the other countries (Basu, et al., 1999). Consistent with this latter view, in 1997-98 the rise in the unemployment rate in the Czech Republic coincided with the fall in GDP and a continued rise in real wages.

Although the overall level of employment did not decline much from 1993 to 1997, we also noted in Table 1 that there was a great deal of restructuring in terms of sector of employment. Was this being done at least cost to the workers and to the economy - i.e., with workers moving from one job to another without passing through a spell of joblessness (denoted $P_{e e j}$ )? These transitions, a subset of the $P_{e e}$, are not reported in Table 2 since they are not available for most of the other studies. We find that in the Czech Republic the job-to-job flows grew over the three years as the economy pulled out of the 1990-92 recession but then fell in 1997 and 1998 as GDP growth slowed down and subsequently declined. In particular, the $P_{e e j}$ rose from 0.025 in 1994 to 0.058 in 1996, but fell to 0.035 in $1998 .{ }^{14}$ How do these flows compare to other countries? A paper by Lehmann and Wadsworth (1999) indicates that in 1996 job-to-job flows were higher in Russia (0.112) and Britain (0.099) and about the same in Poland (0.054). ${ }^{15}$ A paper by 
Abraham and Vodopivec (1995) measure job-to-job flows in Slovenia in the range of 0.049 to 0.072 during 1987 to 1991 . Hence we conclude from this limited evidence that job-to-job mobility was not relatively high but it was at least moving in the right direction, reflecting flexibility in terms of changing demand conditions.

Assuming that workers find similarly productive jobs from search on-the-job as from search while unemployed, the second best scenario in terms of costs to the worker and society is to have a low duration of unemployment. As seen from Table 2, the duration of unemployment can deduced to be relatively short from the rate at which individuals exit unemployment for a job $\left(P_{u e}\right)$. Until 1998, a higher proportion of the unemployed individuals in the Czech Republic (between 0.43 and 0.50) obtained employment within the year than in the other transition economies, except Russia in 1992-93. Nevertheless, in none of these countries did the rates of mobility out of unemployment to a job approach the values of these rates in the US, where two-thirds of the unemployed find a job over the course of a year.

In sum, we find that the large shifts in the sectoral structure of employment that occurred in the Czech Republic in 1994-1998 were brought about with a relatively low incidence and duration of unemployment. Moreover, while the economy was growing during 1994-1996, the shifts were increasingly made with job-to-job flows. However, as GDP fell in 1998, job-to-job flows declined and the duration of unemployment rose to levels similar in the other transition economies. In the next section we examine the nature of the adjustment in each industrial sector. 


\subsection{Dynamics of Net Changes in the Industrial Structure of Employment}

We noted in Table 1 above that the sectors with the greatest declines in employment over the 1994-1998 period were agriculture and industry and those with the most rapid employment growth were construction, financial services, wholesale and retail trade, and hotels and restaurants. In this section we examine the underlying dynamics of these net changes. To what extent were people changing industrial sectors when they changed jobs? Is the incidence of changing sector higher for those individuals with jobs in declining sectors than for those with jobs originally in growing sectors? Were outflows higher in declining sectors?

To address these questions we compare sector of previous job with sector of current job and we report in Table 3 the summary results of the large matrix. ${ }^{16}$ The table is divided into three panels according to the labor market status of the individuals when we first observe them (in the first quarter of each year). ${ }^{17}$ The figures indicate the extent to which people stayed in the same sector or flowed out to another sector when they changed jobs, as well as the share that came into a sector from another sector.

The first striking finding is the degree to which sector of job is being changed. About one-half of the people who changed jobs, changed their sector of job. The second finding is that people who were unemployed or out-of-the labor force were more likely to change their sector of job than job-to-job changers. On average, 48 percent of the job-tojob movers changed sector, as compared to 56 percent of the unemployed and 54 percent of the individuals who found a new job after being out-of-the labor force.

[Table 3 about here] 
Where did they tend to go? Judging by the proportions of people who flowed into a given sector, those who were unemployed or out of the labor force had a higher probability of finding a job in other services, public administration or financial services than in any other sector. On the other hand, the employed were more likely to take a job in the transportation or financial service sectors than any other sector.

Of the three sectors with the highest outflows, two (financial services and other services) are growing industries and one (agriculture) is a declining industry, which means outflows alone do not determine whether a sector is a declining or growing sector. Inflows in the financial sector are also relatively high. As they are growing and creating more employment over time, transportation and financial services have the highest movement of people into and out of these sectors. ${ }^{18}$

\section{Determinants of Individual Transitions}

All these flows are being driven by numerous factors in the supply and demand for labor. Whereas the introduction of market forces may be considered the dominant factor in explaining mobility across labor market states within or across sectors, we must not forget that other determinants are also at play. For example, the extent to which a sector has proportionately more young women, or more older people, may explain why exits out of the labor force are more prevalent than exits to unemployment in that sector. Hence, in this section we use multivariate analysis of several determinants of these flows, including sector of job, demographic characteristics and local demand conditions in the labor market in which the individuals reside.

\subsection{Model Specification}


We estimate hazards using five years of quarterly panel data for individual cohorts from the 1994-1998 Czech Labor Force Surveys. Our right-hand-side variables include static demographic characteristics (age, education (in years), and dummy variables for married men, married women, single men (the base) and single women) ${ }^{19}$ and a time varying demand variable, the quarterly district vacancy rate. ${ }^{20}$ In order to learn which sectors have more labor mobility, ceteris paribus, we include dummy variables for five industrial sectors. ${ }^{21}$ We also include the log of the number of months the individual's spell of employment (or unemployment) to control for duration dependence and, to some extent capture unobserved heterogeneity. ${ }^{22}$ Finally, four annual dummy variables are included with 1994 as the base to allow for year-to-year changes in the base probabilities, due to national demand conditions or other annual shocks. ${ }^{23}$

Appendix Table A1 provides the means and variances of the variables in the first quarter of each year. The demographic characteristics differ for the people in each of the three labor market states: the unemployed tend to be younger than the employed (mean of 34 and 39, respectively) and the people out of the labor force far older (whose mean age is 53 years). The average number of years of education (11-12) is not significantly different between the three groups. Married people are more likely to be employed than single people who tend to be unemployed (especially single men) or out of the labor force (especially single women). Unfortunately, about one-fifth of the unemployed and as many as three-quarters of those out-of-the labor force do not know the sector of their previous job. ${ }^{24}$ When we exclude this group and adjust the proportions to add to 1.0, we are able compare the structure of the industrial sectors across the three groups. This frequency reveals that the unemployed and those out-of-the labor force are more likely to 
have worked in agriculture than the employed. The average vacancy rate for the three cohorts ranges from 0.016 to 0.017 , indicating that on average there is no significant difference in the vacancy rates of the districts where the employed vs. unemployed samples are located.

The estimated coefficients and standard errors for the hazard functions are presented according to the state of origin in the three panels of Table 4. Table 5 contains the ten transition probabilities (hazards) for people with specific characteristics. The base hazard is for a single man, 40 years of age, with 12 years of education (equivalent to vocational or academic high school), the average duration in the current state (90 months for the employed and 10 months for the unemployed), working (or having worked) in the agricultural sector in a district with the average vacancy rate and for the year 1994. Each subsequent row in Table 5 alters one of these characteristics in order to identify the marginal impact of a unit change in each variable. We first describe the findings for all the determinants of $\mathrm{P}_{\text {eej }}, \mathrm{P}_{\mathrm{eu}}$ and $\mathrm{P}_{\mathrm{ue}}$ since we have argued that these are important for examining the effectiveness and "efficiency" of restructuring. We then examine the variation in flows across demographic groups, sectors and local demand conditions.

[Tables 4 and 5 about here]

\subsection{Determinants of $P_{\text {eej }}, P_{\text {eu }}$ and $P_{u e}$}

Job-to-Job Mobility. The estimated hazard function coefficients for the determinants of job-to-job mobility are reported in the first column of Table 4. They indicate that individuals with the following characteristics are more likely to move from one job to another without passing through a spell of joblessness: younger, less educated, single men, people living in districts with higher vacancy rates, people with shorter job 
tenure, and whose job at origin is in the public sector (as compared to people with the opposite characteristics).

The probabilities that people with different characteristics make the job-to-job transition in any quarter (given they are employed in that quarter) are provided in the second column of Table 5. For example the base probability 0.0082 falls to 0.0071 as the age of the individual (all other characteristics held constant) is raised from 40 to 53 . The marginal impact of an additional year of education is larger (-4.9 percent) than the marginal effect of an additional year of age (-1.1 percent). ${ }^{25}$ The probability that a married man makes a job-to-job transition is thirty percent lower than that of a single man ceteris paribus $(0.0058$ vs. 0.0082$)$. The probability for single women is nearly twothirds that for single men and for married women it is about one-half. Job tenure has a large effect: a 10 percent increase in the mean number of months on the job reduces the base probability by eight percent (from 0.0084 to 0.0075 ). Those working in the public sector have a $P_{e e j}$ of 0.0106 , which is 28 percent higher than the probability for those working in agriculture or any other sector (since the other sector coefficients are not significant). ${ }^{26} \mathrm{~A} 10$ percent increase in the average local vacancy rate raises the probability by 1.1 percent. Finally, the job-to-job transition rate was lowest in 1994, the base year. It rose to about 2.3 times this base rate in 1995 and 1996 and then it receded to 1.9 times the 1994 base rate in 1997 and 1.5 times this rate in $1998 .^{27}$

Exits from Employment to Unemployment. The coefficients for the hazards from employment to unemployment are reported in column 2 of Table 4 . They indicate that younger, less educated, single men with short employment durations, working in the construction or trade sectors, and living in districts with relatively low vacancy rates are 
more likely to loose or quit their jobs and become unemployed than people with the opposite characteristics. The base quarterly hazard is 0.0061 in 1994 for a single man with the "base characteristics" (column 3 of Table 5). We only highlight that in 1995 and 1996, when the economy was growing most rapidly, the $P_{e u}$ 's were 20-30 percent lower than in any other year. The marginal impact of an additional year of education (-17.4 percent) is again larger than an additional year of age (- 1.4 percent). People who are not in a job very long are more likely to become unemployed: as job tenure is increased by 10 percent, the $P_{e u}$ falls by 5 percent. The hazards for people who had previously worked in construction and trade is 33 and 43 percent higher, respectively, than the hazard for people who and worked in any other sectors.

Exits from Unemployment to Employment. The estimated coefficients from these hazards indicate that people with the following characteristics tend to find a job faster: younger (2.1 percent per year), more educated (9.0 percent per year), married men (higher than for married women or single men, who in turn have a higher probability than single women), people with shorter unemployment spells and working in districts or years with better demand conditions. As seen in Table 5, the base quarterly hazard is 0.210 and it fluctuates a great deal with changes in demographic characteristics. We note only two outstanding features: married men $\mathrm{P}_{\mathrm{ue}}$ 's are almost 50 percent higher than others' are ceteris paribus. Demand conditions matter: the hazard is positively correlated with the local vacancy rate and it declined when GDP fell in 1998.

We next discuss our findings for all six flows by groups of determinants: demographic characteristics, sector, and demand conditions.

\subsection{Demographic Determinants}


Consistent with the literature, age and education are highly significant determinants of all the labor market flows. ${ }^{28}$ Older people are less likely to a) make a job-to-job move, b) become unemployed or c) find employment and they are more likely to leave the labor market. More educated individuals are less likely to lose/leave their jobs (for another job, to unemployment or to out-of-the labor force) and they are more likely to become employed (out of unemployment or out of the labor force) or to flow from $\mathrm{U}$ to $\mathrm{O}$ or $\mathrm{O}$ to $\mathrm{U}$.

With respect to gender and marital status, we find that single men are least likely to stay employed and most likely to change jobs or leave a job for unemployment or nonparticipation compared to married men and married or single women. Once unemployed, single men and women have a more difficult time leaving unemployment than married men or women. Women (married or single) are less likely than men to find employment when out-of-the labor force.

How do these findings compare with those from studies in other transition economies? The findings for determinants of $P_{e u}$ 's and $P_{u e}$ 's in Bulgaria, East Germany, Poland and Russia are summarized in Table 6. They indicate that the demographic characteristics of the people who are more likely to make these two transitions are very similar in all these transition economies, including the Czech Republic. With some exceptions, the younger, less educated, female, and single individuals tend to have higher $P_{e u}$ 's. Moreover, individuals with high $P_{u e}$ 's are more likely to be younger, more educated, male and single individuals. The main exception is in Russia where men are more likely than women to become unemployed (from a job) and less likely to find a job, once unemployed. The only other studies which report the demographic characteristics of 
job-to-job movers in transition economies are Abraham and Vodopivec (1995) for Slovenia (during 1987 and 1991), and Lehmann and Wadsworth (1999) for Poland and Russia (during 1994-1996). The findings for Poland and Russia are quite similar to ours for the Czech Republic: the younger, less educated, single men are more likely to make job-to-job moves. However, because in the Slovenian study the job-to-job logits were estimated separately for each of three years, and age and education were entered as dummies for grouped variables, the findings do not have a clear pattern.

Hence we conclude that younger people are being driven by the restructuring process (willingly or unwillingly) to change jobs and become and remain unemployed compared to the older population. The more educated are experiencing more job stability and are more likely than the less educated to be hired if unemployed or out of the labor force. The story with respect to gender and marital status is more complex, however it can be said that single men are clearly the most mobile in terms of highest probability of changing jobs, becoming unemployment and leaving the labor market. However, they are less likely than married men (or married women) to leave unemployment for a job.

Finally, how long an individual is employed or unemployed also explains the probability of leaving that state. Those with longer job tenure are more likely to stay in a job and less likely to leave for another job, unemployment, or non-participation. Similarly, there is negative duration dependence among the unemployed: those with longer unemployment spells are less likely to leave.

\subsection{Differences in Flows by Sector of Job}

After controlling for both demographic characteristics and changing demand conditions, we find a systematic difference among the flows by major sectors. First, 
almost all labor market flows of people with jobs in industry are not significantly different from flows of their counterparts in agriculture, the other declining sector. Second, most of the coefficients on the two aggregated, most rapidly growing sectors (construction and trade, with the latter also including transportation financial services, and hotels and restaurants) are not significantly different from each other and yet are significantly different from those in agriculture (and industry). ${ }^{29}$ Hence, we conclude that the flows in sectors where there has been net employment growth differ systematically from the flows in the declining sectors.

To be specific, individuals with jobs in the growing sectors are more likely to leave a job for unemployment (higher $\mathrm{P}_{\mathrm{eu}}$ ) and less likely to leave a job to go out of the labor force (lower $\mathrm{P}_{\mathrm{eo}}$ ) than individuals with jobs in declining sectors. However, there are no significant differences in their job-to-job flows $\left(\mathrm{P}_{\text {eej }}\right)$. Similarly, the exits from unemployment differ systematically with exits from unemployment to a job ( $\left.\mathrm{P}_{\text {ue }}\right)$ being higher and exits from unemployment to non-participation $\left(\mathrm{P}_{\text {чо }}\right)$ being lower from people who had jobs in the growing sectors as compared to those who had jobs in the declining sectors. ${ }^{30}$ For the exits from non-participation $\left(\mathrm{P}_{\mathrm{oe}}\right.$ and $\left.\mathrm{P}_{\mathrm{ou}}\right)$ there is not much difference in the coefficients on industry, construction and trade. ${ }^{31}$ Finally, it is noteworthy that individuals with jobs (currently or previously) in the intermediate growing sector -- the public sector -- have a different pattern of flows from the others. ${ }^{32}$

\subsection{Impact of Demand}

We find that demand conditions matter, both local demand, proxied with quarterly district vacancy rates and national demand shocks, proxied with annual dummies. We show that quarterly fluctuations in local demand affect decisions about mobility between 
unemployment and employment, but not to or from non-participation. On the other hand, changes in annual national conditions affect all flows.

Specifically, as one would expect, flows from unemployment to a job $\left(\mathrm{P}_{\mathrm{ue}}\right)$ and from job-to-job $\left(\mathrm{P}_{\text {eej }}\right)$ are positively correlated with local demand conditions. The probability that an unemployed person finds a job $\left(P_{u e}\right)$ increased by 0.35 for a onepercent increase in the local vacancy rate. We estimated an elasticity of 0.11 for the jobto-job hazard with respect to a change in the local vacancy rate. The coefficients on the annual dummies indicate that these flows have different reaction times with respect to changes in aggregate GDP growth. Job-to-job flows were highest (and not significantly different) in 1995 and 1996, when the GDP was growing the fastest and declined in 1997 and 1998, when the economy slowed down. ${ }^{33}$ On the other hand, exits from unemployment to a job do not differ significantly over the 1994-1997 period, and only fall when the economy declined dramatically in 1998.

We also confirm that flows from employment to unemployment $\left(\mathrm{P}_{\mathrm{eu}}\right)$ fall when local and national demand conditions improve. The probability that an employed person becomes unemployed $\left(P_{e u}\right)$ declines by 0.23 percent with a one percent increase in the local vacancy rate. The coefficients on the year dummies indicate that these hazards were lowest in 1995 and 1996 when the economy was growing most rapidly.

With respect to flows to and from non-participation, we find that individuals are less likely to leave jobs for non-participation and to finds jobs from non-participation when national, longer term (annual) demand conditions worsen but this behavior is unaffected by variation in shorter term (quarterly) local demand conditions. This is not surprising since many decisions to leave the labor force (e.g., retirement, child bearing) 
are more directly influenced by the life cycle and the business cycle than by short-term local demand variations.

\section{Summary and Conclusions}

In this paper we provide a comparative analysis of the extent and direction of mobility in the Czech transitional labor market. We follow the movements of fifteen cohorts of working age individuals across the three labor market states of employment (E), unemployment (U) and out-of-the labor force (O) during 1994-1998 using quarterly Labor Force Surveys of the Czech Republic. We first calculate gross probabilities of mobility and then estimate hazard functions with micro data. In assessing the functioning of the transitional labor market, we focus on two sets of questions: i) How much restructuring has occurred in terms of sectoral shifts and to what extent has the adjustment been carried out at least cost to the worker and the economy? (We define this as restructuring with relatively more job-to-job, rather than job-unemployment-job, flows and with relatively short spells of unemployment vis a vis other transitional economies.)

ii) What are the determinants of these transition probabilities in terms of the individuals' demographic characteristics, sector of job, and demand conditions at the time they are considering the transition?

We conclude that there has been a significant shift in the structure of employment by industrial sector. The largest declines in employment are in the two largest sectors: agriculture and industry. The sectors with the highest rate of employment growth are the ones that had not been considered important under communism: financial services and trade and hotels and restaurants. About one half of the people who change jobs also change their sector of employment. We show that until 1998, changes in the employment 
structure were brought about relative efficiently, with lower incidence and shorter spells of unemployment compared to the other transitional economies and relying increasingly on job-to-job.

From the individual hazard analysis we identify which demographic groups have been experiencing more mobility. We find that younger people are more mobile than older individuals: they are more likely to change jobs for another job or unemployment and once unemployed, more likely to find a job. People with less education do not fare as well as those with more education. The less educated are less likely to stay employed, more likely to change jobs for another job, or to unemployment or non-participation, and more likely to stay unemployed or out-of-the labor force. In terms of gender and marital status, we find that married men are most likely to keep their jobs (compared to single men and single and married women) and if unemployed, are most likely to find a job. Single men are most likely to experience job-to-job flows and to become unemployed. Many of these findings are consistent with the empirical search literature for the U.S. and other transition economies.

The hazard analysis also indicates that people with jobs in declining sectors experience systematically different flows than people with jobs in growing sectors. Those who work in agriculture or industry are more likely to leave the labor force from a job or unemployment and less likely to find a job (in any sector) once unemployed or out of the labor force. On the other hand, individuals with jobs in growing sectors are not more likely than those with jobs in declining sectors to stay employed. They are, however, more likely to become unemployed, although they do leave unemployment for a job more rapidly than individuals who previously held jobs in either declining sector. 
Finally, we show that the labor market has been very responsive to changes in demand conditions, both at the local and national level. In sum, we find there has been a significant amount of restructuring and it was carried out with relatively low incidence and duration of unemployment, when compared to the other transition economies. We show, as in these other economies, single men with less human capital are more likely to be involved in the restructuring process through their higher mobility from job-to-job and from jobs to unemployment. Hence we conclude that the Czech labor market has demonstrated flexibility and efficiency in the transition. 


\section{Footnotes}

1 For a flow analysis of an early transition economy, see Bellman et al. (1995)

2 Prices in some sectors, such as utilities and housing, are still subsidized and only slowly being liberalized.

3 Czech Statistical Office (CSO) firm level data. The Labor Force Survey does not ask questions on public-private ownership.

4 EBRD Transition Report 1998 and 1999. GDP growth slowed down in 1997 as a result of a number of factors: The decline in export growth which prompted a depreciation of the crown by 10 percent in May 1997; a natural disaster in July; and a scandal which forced the Prime Minister's resignation in December 1997.

5 The quarters are as follows: $1 \mathrm{Q}=$ November-January; $2 \mathrm{Q}=$ February - April; $3 \mathrm{Q}=$ May-July; 4Q= August-October.

6 The first sample in 2Q93 was smaller, only two-thirds, of the others. The CSO did this in order to introduce a new cohort in 3Q93 and hence allow them to carry out the rotation scheme.

7 We also know the industrial sector of the job and we make use of this information in Section 4.

$8 \quad$ This analytical approach has been used, among others, by Marston (1976) with U.S. data, and in the transitional economies by Bellmann, et al. (1995), Lehmann and Wadsworth (1999) and by Foley (1997).

9 One pattern of multiple moves is where the individual moves away from a state and returns to it by the end of the year — "round tripping." Our estimates of round 
tripping - the number of people who left and returned to the original state within the year, as a percent of those in the state at the beginning of the year - are as follows: $0.9 \%$ for the employed, $3.5 \%$ for the unemployed and $0.6 \%$ for those out of the labor force (averages for the five years).

This formulation assumes the cumulative distribution of the error terms is logistic. In the common alternative to this model, the probit, the error terms are assumed to be normally distributed. Because the cumulative normal distribution and the logistic distribution are very close to each other, except at the tails, the results are not likely to be very different, unless the samples are large and there are enough observations in the tails. In order to ensure that this condition is not operable, we estimated the model using both the logit and the probit functional forms. No significant differences in the results were observed, hence only the logit results are reported in the body of the paper. The results based on the probit specification can be found in the appendix. See Devine and Kiefer (1991) for further discussion of hazard functions.

11 We are free to control for pre-baseline hazard under the assumption of no unobserved heterogeneity.

12 Of less importance in terms of restructuring, but notable nonetheless is that there is also less mobility in the Czech Republic among individuals who leave the labor force. Once a Czech leaves the labor market, he/she tends to stay out, as seen by the relatively high $P_{o o}$ (except Slovakia and the US). Whereas in the US 0.20 of those out of the labor force at the beginning of the year find a job $\left(P_{o e}\right)$ or are actively seeking a job by the end of the year $\left(P_{o u}\right)$, the probability that someone returns to the 
labor force $\left(P_{o e}+P_{o u}\right)$ in the Czech Republic is about 0.06 and in the other transition countries it ranges from 0.10 to 0.20 . If this reflects in part government policies in the Czech Republic that provided disincentives for retired people to return to the labor market (e.g., reduction of pension or higher tax on earnings for pensioners), it means fewer older individuals were competing for jobs in the labor market. In Russia, the other country for which we have transition probabilities several years apart, the pattern is one of declining $P_{e e}$ 's. This can be explained in part by the fact that 1992-93 was the first year of the market-oriented reforms in Russia and not much adjustment had yet taken place. Basu, Estrin and Svejnar (1999) show that Russian firms were not systematically adjusting employment with respect to changes in wages and output in 1992-93 when the Russian unemployment rate was low (5 percent). However, by 1995-1996 the Russian $P_{e e}$ 's fall in line with the other countries and unemployment rose to 8 and 9 percent.

14 What we in fact observe is that someone changed jobs (employers) from one quarter to the next. It is possible that some of these individuals passed through a very short spell of unemployment between the two quarters. We are unable to check what percent might have experienced unemployment because the variable for duration of unemployment is coded in a grouped form as '1-3 months,' '3-6 months,' etc.

15 The Russian finding is particularly interesting in view of the dismal aggregate economic performance in Russia. It suggests that the Russian labor market may be a relatively flexible part of the otherwise malfunctioning economy. 
16 Table 3 is derived from the diagonal and the final row and column of a matrix of sector at origin and sector at destination for each cohort. We did not find any significant pattern in the flows from one sector or group of sectors to another and hence do not present this larger matrix. We have aggregated some of the sectors shown in Table 1. To be clear: 'Agriculture' also includes forestry and mining (as in Table1); 'Industry' includes manufacturing and utilities (as in Table1); 'Construction' is simply construction (as in Table1); 'Trade' includes wholesale and retail trade and hotels and restaurants; 'Transport' includes storage and communication, telecommunication and postal services; 'Financial services' includes banking, insurance and real estate; 'Public administration' includes public administration, defense, education, judicial services, health and social work; 'other service activities' includes recreation and cultural services, and all other services (as in Table 1).

17 In panels B and C of Table 3 the "sector of job" refers to the industrial sector of the individual's job prior to being unemployed or out-of-the labor force. Hence, there is more time variation for these observations than in panel $\mathrm{A}$, where the observation for job sector refers to the first quarter of the year for everyone. Moreover, the dispersion in the dates that these jobs were last held is likely to be wider for the nonparticipants as compared to the unemployed (who probably left a job less than one year prior to our observation). We do not know the date that someone left the labor force, hence we cannot determine the degree of variation. 
See Earle (1997) for a similar analysis of the industrial sector in Romania, where he also finds that sectors with more outflows are also likely to be hiring more new workers.

19 The category 'single' includes widowed and divorced people as well as those who never married.

The district vacancy rate is defined as the number of vacancies divided by the labor force in the district. Although in the Czech Republic employers are required by law to report vacancies, the number of vacancies may be underreported. However, there is no reason to believe that the level of underreporting varies across districts or over time and hence the vacancy rates are capturing changes in demand conditions that are relevant for our analysis. We have been asked by the referees to consider using the unemployment rate (UR) in addition or instead of the vacancy rate (VR). Including both the UR and VR would of course make the re-employment hazards comparable to the macro matching function literature (as shown by Petrongolo, 1999). However, we have decided against using the unemployment rate as a determinant of all these flows since it is endogenous and linked to all the flows through an identity. As shown by Marston (1976):

$$
\mathrm{UR}=\frac{1}{1+\left[\frac{(\text { Poe }+ \text { Pou }) \text { Pue }+ \text { Poe } \cdot \text { Puo }}{(\text { Poe }+ \text { Pou }) \text { Peu }+ \text { Pou } \cdot \text { Peo }}\right]} .
$$


Nevertheless, following the two referees' recommendations, we re-estimated all seven hazard functions with UR and VR and found that this did not affect the coefficients on any of the other variables (demographic, sector or annual shocks). except that two sectors have been further aggregated: 'Trade' includes 'transport' and 'financial services', in addition to trade, hotels and restaurants. The 'public sector' now includes, 'other services' in addition to 'public administration.'

22 The probability that one exits a labor market state for another may be dependent on how long someone is in the original state. For example, negative duration dependence implies that the longer one is in a state that less likely he/she is to leave that state. This may be due to unobserved heterogeneity, if as is often believed to be the case for the unemployed, those who are unemployed for longer spells are less motivated, or have other characteristics that make them less favorable to employers. Upon the suggestion of a referee, we also test the extent to which labor market flows are affected by the shadow economy and "illegal" commuting for work in the border countries. It is hypothesized that the flows into (out of) inactivity would be higher (lower) in large cities where, the shadow economy would be expected to be higher, and in border districts, where people could find work by commuting. We estimated the logit hazard with the variables specified above plus a dummy variable for Prague (the largest city) and dummies for the border districts, differentiating between the borders of former East Germany (8 districts), West Germany (5 districts), and Austria (5 districts). We did not find much support for this hypothesis and hence do 
not report these results other than to say that many of the coefficients were not significantly different from zero and there was no clear pattern regarding the flows into and out of inactivity.

Of the unemployed that do not know their previous sector, 61 percent are new entrants to the labor force. However, among the population out-of-the labor force only 32 percent of those that do not know the sector of previous job had never worked before. percent. Interestingly, Earle (1999) also found higher job turnover among the public sector workers in Romania.

27 The chi square test indicates that the difference between the 1997 and 1998 coefficients is significant at the 1 percent confidence level.

28 See Devine and Keifer (1991) for a review of the empirical findings for the U.S. and we will show below the similar findings in the transition economies.

29 The coefficients on the two growing sectors, trade and construction, are not significantly different at the 5 percent level for all flows except those out of $\mathrm{O}$ (from $\mathrm{O}$ to $\mathrm{E}$ and from $\mathrm{O}$ to $\mathrm{U}$ ).

30 The coefficient on the construction dummy for the $\mathrm{P}_{\mathrm{ue}}$ is positive and has a $\mathrm{P}$ value of 0.112 . 
31 The exception is that people previously employed in industry are less likely to reenter the labor force and those previously employed in construction are more likely to re-enter (compared to those previously employed in agriculture). People in public sector jobs are more likely to change jobs without a spell of joblessness $\left(\mathrm{P}_{\text {eej }}\right)$ and much less likely to re-enter the labor force (lower $\mathrm{P}_{\mathrm{oe}}$ and $\left.\mathrm{P}_{\mathrm{ou}}\right)$.

33 The equality of the coefficients on the 1997 and 1998 dummy variables can be rejected at the 1 percent confidence level, as well as the equality of either of these coefficients with those on the 1995 and 1996 variables. 


\section{References}

Abraham, Katherine and Vodopivec, Milan, "Slovenia: A Study of Labor Market Transitions," Policy Research Working Paper, Washington, D.C.: the World Bank, 1995.

Basu, Swati, Estrin, Saul, and Svejnar, Jan, "Employment and Wage Behavior of Enterprises under Communism and in Transition: Evidence from Central Europe and Russia," Davidson Institute Working Paper, University of Michigan Business School, revised in January, 1999.

Bellmann, Lutz, Estrin, Saul, Lehmann, Hartmut, and Wadsworth, Jonathan, “The East German Labor Market in Transition: Gross Flow Estimates from Panel Data.” Journal of Comparative Economics, 20(2):139-170, 1995.

Boeri, Tito, "Labor Market Flows in the Midst of Structural Change." In S. Commander, Ed., Enterprise Restructuring and Unemployment in Models of Transition. EDI Development Studies, Wash., D.C.: The World Bank, 1998.

Devine, Theresa J. and Nicholas M. Kiefer, Empirical Labor Economics: The Search Approach. New York: Oxford University Press, 1991.

Earle, John, "Industry Decline and Labor Allocation in Romania," unpublished paper, 1997.

Faggio, Giula and Jozef Konings, "Gross Job Flows in Transition Countries: Results for Estonia, Poland, Bulgaria and Romania," LICOS Center for Transition Economics, Catholic University of Leuven, Belgium, unpublished paper, April, 1999. 
Foley, Mark C., "Labor Market Dynamics in Russia," Yale University, Economic Growth Center Discussion Paper No. 780, 1997.

Gora, Marek, and Lehmann, Hartmut, "How Divergent is Regional Labour Market Adjustment in Poland?" in S. Scarpetta and A. Woergoetter, Eds., The Regional Dimension of Unemployment in Transition Countries: A Challenge for Labour Market and Social Policies, OECD, Paris, 1995.

Ham, John, Svejnar, Jan, and Terrell, Katherine, "Unemployment and the Social Safety Net During the Transition to a Market Economy: Evidence from Czech and Slovak Men.” American Economic Review, 88(5):1117-1142, 1998.

Ham, John, Svejnar, Jan, and Terrell, Katherine, "Factors Affecting Women's Unemployment Duration during the Transition the Czech and Slovak Republics.” Economics of Transition, 7(1):47-78, 1999.

Jones, Derek C., and Kato, Takao, "The Nature and the Determinants of Labor Market Transitions in Former Communist Economies: Evidence from Bulgaria." Industrial Relations, 36(2):229-254, 1997.

King, Arthur E., and Adamchik, Vera A., “The Impact of Private Sector Development on Unemployment, Labor Force Reallocation and Labor Market Flows in Poland," unpublished paper presented at the annual meetings of the ACES, New York, Jan. 2-4, 1999.

Krueger, Alan B., and Pischke, J. S., "A Comparative Analysis of East and West German Labor Markets: Before and After Unification.” In Freeman, R.B., and Katz, F., Eds., Differences and Changes in Wage Structures, Chicago: The University of Chicago Press, 1995. 
Lehmann, Hartmut, and Wadsworth, Jonathan, "Tenures that Shook the World: Worker Turnover in the Russian Federation and Poland," Centre for Economic Performance Working Paper No. 991, March, 1999.

Marston, Steven, “Employment Instability and High unemployment Rates." Brookings on Economic Activity, 1:169-219, 1976.

Petrongolo, Barbara, "Re-employment Probabilities and Returns to Matching," Unviersidad Carlos III, Madrid, CEPR, April 1999.

Stefanova, Jana, and Terrell, Katherine, “Gender Differences in Flows across Labor Market States in the Czech Republic," unpublished manuscript, University of Michigan, November, 1998. 
Table 1: Changes in the Sectoral Composition of Employment

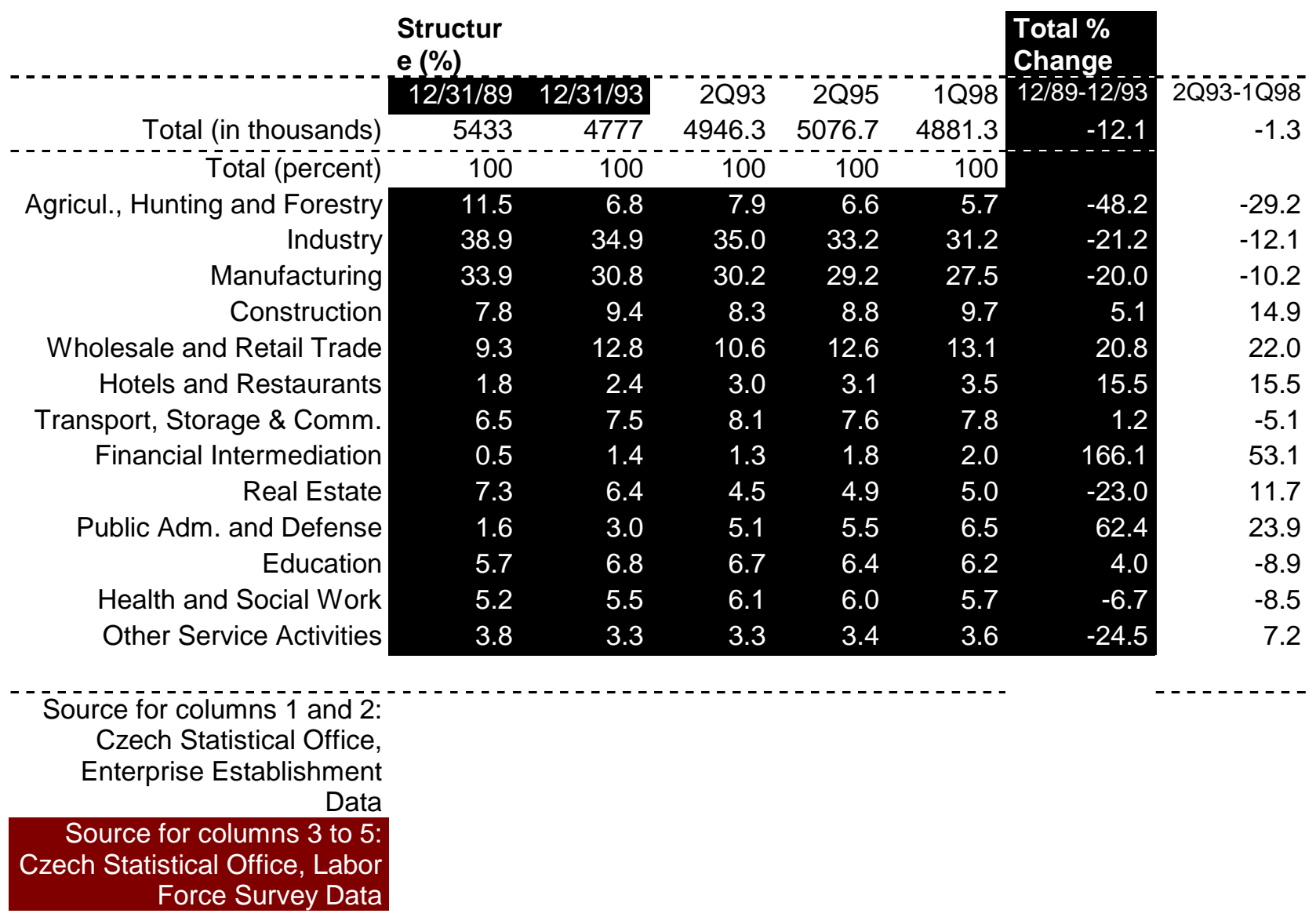

Table 2: Transition

Probabilities for

Six Transition

Economies and the 


\section{US}

\begin{tabular}{r|r|ccc|ccc|c}
\hline Country & Reference Year & Pee $^{*}$ & Peu & Peo & Puu & Pue & Puo & Poo \\
\hline Czech Republic & 1Q1994-4Q1994 & 0.959 & 0.013 & 0.028 & 0.376 & 0.496 & 0.129 & 0.946 \\
Czech Republic & 1Q1995-4Q1995 & 0.966 & 0.010 & 0.025 & 0.391 & 0.479 & 0.130 & 0.945 \\
Czech Republic & 1Q1996-4Q1996 & 0.966 & 0.008 & 0.025 & 0.442 & 0.457 & 0.101 & 0.952 \\
Czech Republic & 1Q1997-4Q1997 & 0.966 & 0.014 & 0.021 & 0.478 & 0.429 & 0.093 & 0.950 \\
Czech Republic & 1Q1998-4Q1998 & 0.957 & 0.018 & 0.025 & 0.575 & 0.335 & 0.090 & 0.946 \\
Other Transitional & & & & & & & & \\
Economies & & & & & & & & 0.864 \\
Bulgaria (1) & $6 / 1994-3 / 1995$ & 0.849 & 0.059 & 0.092 & 0.433 & 0.323 & 0.244 & 0.864 \\
E. Germany (2) & $11 / 1990-11 / 1991$ & 0.836 & 0.093 & 0.071 & 0.373 & 0.350 & 0.277 & 0.799 \\
Poland(3) & $1992-1993$ & 0.884 & 0.040 & 0.076 & 0.481 & 0.361 & 0.158 & 0.860 \\
Poland(3) & $1993-1994$ & 0.897 & 0.040 & 0.063 & 0.487 & 0.354 & 0.159 & 0.883 \\
Russia(4) & $1992-1993$ & 0.910 & 0.032 & 0.058 & 0.323 & 0.520 & 0.157 & 0.899 \\
Russia(4) & $1995-1996$ & 0.881 & 0.056 & 0.062 & 0.459 & 0.395 & 0.145 & 0.891 \\
Slovakia (1) & $1 Q 1994-4 Q 1994$ & 0.932 & 0.023 & 0.045 & 0.685 & 0.237 & 0.078 & 0.965 \\
United States (1) & $1992-1993$ & 0.919 & 0.028 & 0.053 & 0.053 & 0.659 & 0.288 & 0.796 \\
\hline
\end{tabular}

Czech Republic probabilities based on authors' calculations using panel data from the Czech quarterly Labor Force Surveys.

Sources:

(1) Boeri, 1998.

(2) Bellmann et al., 1995.

(3) Gora and Lehmann, 1995. (4) Foley, 1997.

*Includes individuals who kept the same job (employer) as well as

those who changed jobs without a spell of unemployment. 
Table 3: Flows

from Sector of

Previous Job

to Sector

of Current Job

for those who

Changed/Foun

d a Job,

composite

data for 1994-

1998

Panel A:

Employed who

changed jobs

\begin{tabular}{|rrrrr|}
\hline Sector & stayed & flowed out & flowed in & net flows \\
\hline agriculture & 0.3722 & 0.6278 & 0.5167 & -0.1111 \\
industry & 0.5399 & 0.4601 & 0.4803 & 0.0203 \\
construction & 0.4912 & 0.5088 & 0.4912 & -0.0176 \\
trade & 0.5489 & 0.4511 & 0.4666 & 0.0154 \\
transport & 0.4058 & 0.5942 & 0.8986 & 0.3043 \\
financial serv. & 0.3529 & 0.6471 & 0.7794 & 0.1324 \\
pub.adm. & 0.6210 & 0.3790 & 0.3703 & -0.0086 \\
other services & 0.3492 & 0.6508 & 0.4762 & -0.1746 \\
Total & 0.5222 & 0.4778 & 0.4778 & 0.0000
\end{tabular}

Panel B:

Unemployed

who found a

job

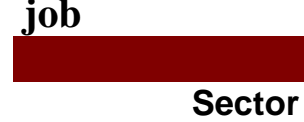

stayed flowed out

flowed in

net flows

agriculture

industry

0.3176

0.6824

0.5288

construction

trade

transport

financial serv.

pub.adm.

other services

0.4712

0.5299

0.4701

0.4896

0.5104

0.8864

0.1136

0.8667

0.5652

0.1935

0.8065

Total

0.4360

0.5641

0.3882

0.4712

0.5299

0.4549

0.9545

1.0667

0.7971

1.2581

0.5641 


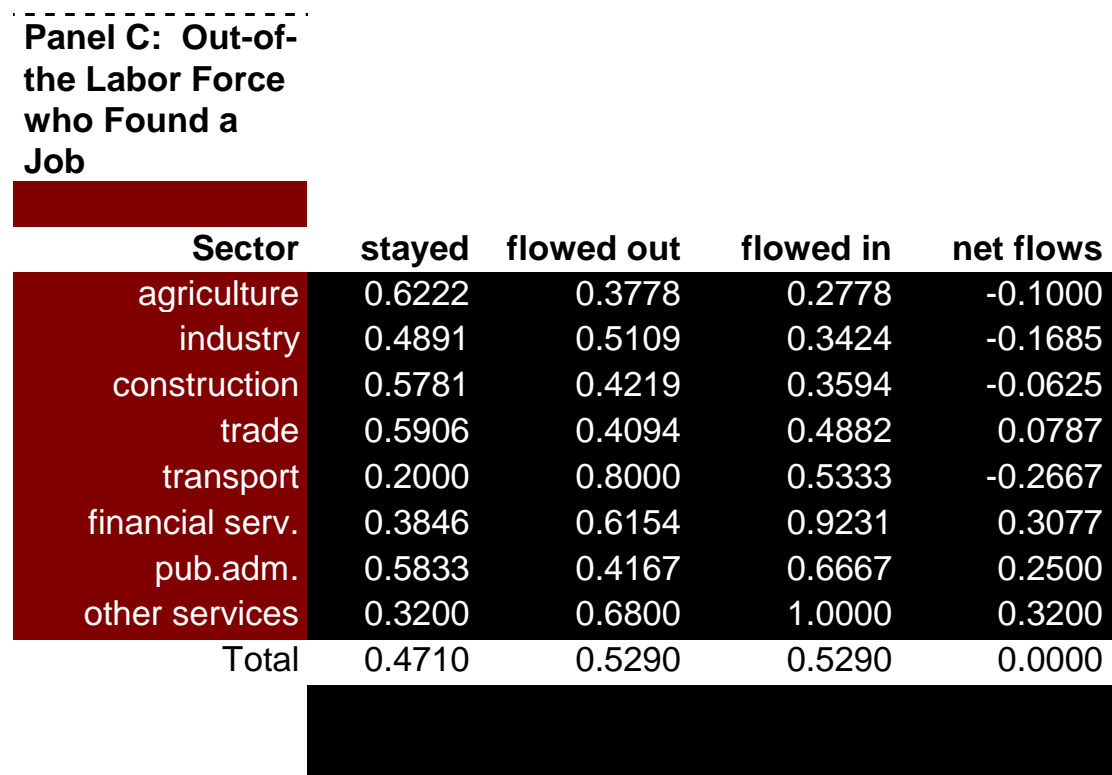

Table 4: Coefficients from the Logit Hazard Models of Exits from Employment

(E),

Unemployment (U) and

Out-of-the Labor Force

(O), 1994 to 1998

(standard errors in

parentheses)

$$
\begin{aligned}
& \begin{array}{ccccccr} 
& \text { Job to Job } & \text { E to U } & \text { E to O } & \text { U to E } & \text { U to O } & \text { O to E } \\
\text { Constant } & -3.051^{\text {a }} & -1.814^{\text {a }} & -5.414^{\text {a }} & -1.970^{\text {a }} & -3.778^{\text {a }} & -3.34
\end{array} \\
& \begin{array}{lllll}
(0.152) & (0.254) \quad(0.191) & (0.250) & (0.369) & (0.181
\end{array} \\
& \begin{array}{ccccccc}
\text { Age } & -0.011^{\mathrm{a}} & -0.014^{\mathrm{a}} & 0.064^{\mathrm{a}} & -0.026^{\mathrm{a}} & 0.024^{\mathrm{a}} & -0.05 \\
& (0.002) & (0.003) & (0.002) & (0.003) & (0.004) & (0.002 \\
\text { Education (yrs.) } & -0.048^{\mathrm{a}} & -0.161^{\mathrm{a}} & -0.093^{\mathrm{a}} & 0.122^{\mathrm{a}} & 0.086^{\mathrm{a}} & 0.24
\end{array} \\
& \begin{array}{lllllll}
\text { Education (yrs.) } & -0.048^{\mathrm{a}} & -0.161^{\mathrm{a}} & -0.093^{\mathrm{a}} & 0.122^{\mathrm{a}} & 0.086^{\mathrm{a}} & 0.24
\end{array} \\
& \text { Marital status1 } \\
& (0.009) \quad(0.017) \\
& (0.011) \quad(0.017) \quad(0.025) \quad(0.010 \\
& \text { Married men } \\
& -0.357^{a}-0.569^{a} \\
& -0.757^{a} \\
& 0.498^{a} \quad-0.049 \\
& -0.06 \\
& (0.053) \quad(0.089) \\
& -0.661^{\text {a }} \quad-0.291^{\text {a }} \\
& (0.080) \\
& \text { (0.105) } \\
& \text { (0.169) } \\
& 0.070 \quad 0.049 \\
& (0.103 \\
& \text { (0.056) (0.085) } \\
& -0.225 \\
& \begin{array}{r}
(0.075) \\
-0.028
\end{array} \\
& \text { (0.093) } \\
& \text { (0.143) } \\
& -0.453^{a} \\
& \text { (0.095) } \\
& (0.090) \\
& -0.160^{\mathrm{c}} \\
& -0.149 \\
& \text { (0.082 } \\
& \text { (0.062) } \\
& -0.006 \\
& \text { (0.096) } \\
& \text { (0.161) } \\
& -0.009^{a} \\
& \text { (0.0010) } \\
& -0.002 \\
& \text { (0.0004) }
\end{aligned}
$$




\begin{tabular}{|c|c|c|c|c|c|c|}
\hline & $(0.079)$ & $(0.122)$ & $(0.084)$ & $(0.135)$ & $(0.185)$ & (0.132 \\
\hline \multirow[t]{2}{*}{ Construction } & 0.109 & $0.291^{b}$ & -0.441 & 0.251 & $-0.745^{a}$ & 0.34 \\
\hline & $(0.090)$ & $(0.142)$ & $(0.124)$ & $(0.156)$ & $(0.257)$ & (0.172 \\
\hline \multirow[t]{2}{*}{ Trade4 } & 0.130 & $0.361^{a}$ & -0.225 & $0.456^{a}$ & $-0.431^{b}$ & -0.21 \\
\hline & $(0.081)$ & $(0.124)$ & $(0.091)$ & $(0.137)$ & $(0.197)$ & (0.138 \\
\hline \multirow[t]{2}{*}{ Public Sector5 } & $0.250^{\mathrm{a}}$ & 0.044 & -0.056 & 0.031 & $-0.574^{a}$ & -0.39 \\
\hline & $(0.080)$ & $(0.127)$ & $(0.086)$ & $(0.144)$ & $(0.204)$ & (0.139 \\
\hline \multirow[t]{2}{*}{ Sector unknown } & -- & -- & -- & -0.224 & 0.062 & -1.35 \\
\hline & -- & -- & -- & $(0.151)$ & $(0.194)$ & $(0.120$ \\
\hline \multirow[t]{2}{*}{ Local Vacancy rate } & $6.926^{a}$ & $-14.076^{a}$ & 4.774 & $24.614^{a}$ & 4.930 & 0.25 \\
\hline & $(2.750)$ & $(4.862)$ & 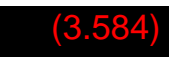 & (4.995) & (8.305) & (3.702 \\
\hline \multicolumn{7}{|l|}{$\begin{array}{r}\text { al Dummies }(1994= \\
\text { base })\end{array}$} \\
\hline \multirow[t]{2}{*}{ Y95 } & $0.884^{a}$ & $-0.234^{b}$ & -0.107 & -0.064 & -0.212 & 0.09 \\
\hline & $(0.069)$ & (0.099) & $(0.075)$ & $(0.106)$ & $(0.160)$ & (0.078 \\
\hline \multirow[t]{2}{*}{ Y96 } & $0.860^{a}$ & $-0.351^{a}$ & -0.117 & -0.189 & $-0.361^{b}$ & -0.04 \\
\hline & $(0.069)$ & $(0.101)$ & $(0.074)$ & $(0.112)$ & $(0.169)$ & $(0.080$ \\
\hline \multirow[t]{2}{*}{ Y97 } & $0.631^{a}$ & -0.042 & -0.280 & -0.116 & $-0.583^{a}$ & -0.13 \\
\hline & $(0.071)$ & $(0.091)$ & $(0.076)$ & $(0.103)$ & $(0.163)$ & $(0.079$ \\
\hline \multirow[t]{2}{*}{ Y98 } & $0.391^{a}$ & 0.092 & -0.139 & $-0.667^{a}$ & $-0.897^{a}$ & -0.28 \\
\hline & $(0.077)$ & $(0.092)$ & $(0.078)$ & $(0.106)$ & $(0.175)$ & $(0.084$ \\
\hline No. of observations & 190,174 & 190,174 & 190,174 & 6,501 & 6,501 & 118,567 \\
\hline Log likelihood & -14432 & -6794 & -9639 & -3055 & -1488 & -7797 \\
\hline
\end{tabular}

SOURCE: annual panels

constructed from $1994-1998$

quarterly Czech Labor Force

Survey.

NOTE: a Significant at the $1 \%$ level; b Significant at the 5\% level;

c Significant at the $10 \%$ level.

2 Agricultural Sector is the base .

3'Industry' includes manufacturing plus utilities.

4 Trade Includes transportation, financial services,

hotels and restaurants in addition to wholesale and retail trade.

5 'Public Sector' includes public administration, defense, education, judicial services, health and social work, and other services.

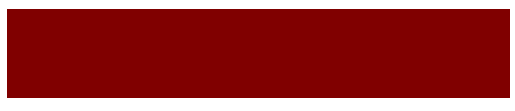

Table 5: Quarterly

Hazard Rate from

Employment (E),

Unemployment (U) and

Out-of-the Labor Force

(O), 1994 to 1998 


\begin{tabular}{|c|c|c|c|c|c|c|c|c|}
\hline & Panel A & Peej & Peu & 86 & anel B & Pue & 烈 & Panel \\
\hline Base Hazard2 & 0.9720 & 0.0082 & 0.0061 & 0.0136 & 0.6501 & 0.2096 & 0.1403 & $v$ \\
\hline Age $=39$ & 0.9727 & 0.0083 & 0.0062 & 0.0128 & 0.6484 & 0.2140 & 0.1375 & \\
\hline Age $=33$ & 0.9756 & 0.0088 & 0.0068 & 0.0088 & 0.6359 & 0.2424 & 0.1217 & \\
\hline Age $=53$ & 0.9572 & 0.0071 & 0.0051 & 0.0306 & 0.6612 & 0.1575 & 0.1813 & \\
\hline Education 11 yrs. & 0.9693 & 0.0086 & 0.0072 & 0.0149 & 0.6792 & 0.1904 & 0.1304 & \\
\hline Married men & 0.9843 & 0.0058 & 0.0035 & 0.0064 & 0.5543 & 0.3059 & 0.1398 & \\
\hline Married women & 0.9788 & 0.0043 & 0.0046 & 0.0123 & 0.6271 & 0.2241 & 0.1488 & \\
\hline Single women & 0.9766 & 0.0052 & 0.0049 & 0.0132 & 0.6930 & 0.1834 & 0.1235 & \\
\hline $\begin{array}{r}\text { Duration (in current state) } \\
\text { increased by } 10 \% \\
\text { Job (current or previous) in: }\end{array}$ & 0.9735 & 0.0075 & 0.0058 & 0.0131 & 0.6541 & 0.2059 & 0.1400 & \\
\hline Manufacturing & 0.9722 & 0.0088 & 0.0071 & 0.0119 & 0.6579 & 0.2376 & 0.1045 & \\
\hline Construction & 0.9738 & 0.0092 & 0.0082 & 0.0088 & 0.6746 & 0.2533 & 0.0721 & \\
\hline Trade & 0.9710 & 0.0093 & 0.0088 & 0.0109 & 0.6042 & 0.2951 & 0.1007 & \\
\hline $\begin{array}{l}\text { Public Sector } \\
\text { Vacancy rate }\end{array}$ & 0.9702 & 0.0105 & 0.0064 & 0.0129 & 0.6981 & 0.2132 & 0.0887 & \\
\hline increased by $10 \%$ & 0.9720 & 0.0083 & 0.0060 & 0.0137 & 0.6421 & 0.2169 & 0.1410 & \\
\hline Y95 & 0.9632 & 0.0197 & 0.0049 & 0.0122 & 0.6890 & 0.1880 & 0.1230 & \\
\hline Y96 & 0.9644 & 0.0192 & 0.0043 & 0.0121 & 0.7214 & 0.1750 & 0.1036 & \\
\hline Y97 & 0.9685 & 0.0153 & 0.0059 & 0.0103 & 0.7305 & 0.1868 & 0.0827 & \\
\hline Y98 & 0.9693 & 0.0121 & 0.0068 & 0.0119 & 0.8201 & 0.1175 & 0.0625 & \\
\hline
\end{tabular}

SOURCE: Based on hazard estimates in Table 4.

employed in the same job (same employer) from one quarter to the next. It hence excludes those who changed jobs (employers) from one quarter to the next (Peej). (avg. for $E=39$, avg. for $\mathrm{O}=53$, avg. for $\mathrm{U}=34$ ), 12 years of education (avg. for $E=12$, avg. for $U$

avg. for $\mathrm{O}=11$ ), working (or having worked) in the agricultural sector, with average duration in the state (avg. for $\mathrm{E}=90$, avg. for $\mathrm{O}=$ n.a., avg. for $U=10$ ), living in a district with average vacancy rate $(0.017)$ in 1994 .

Table 6:

Demographic

Characteristics of 


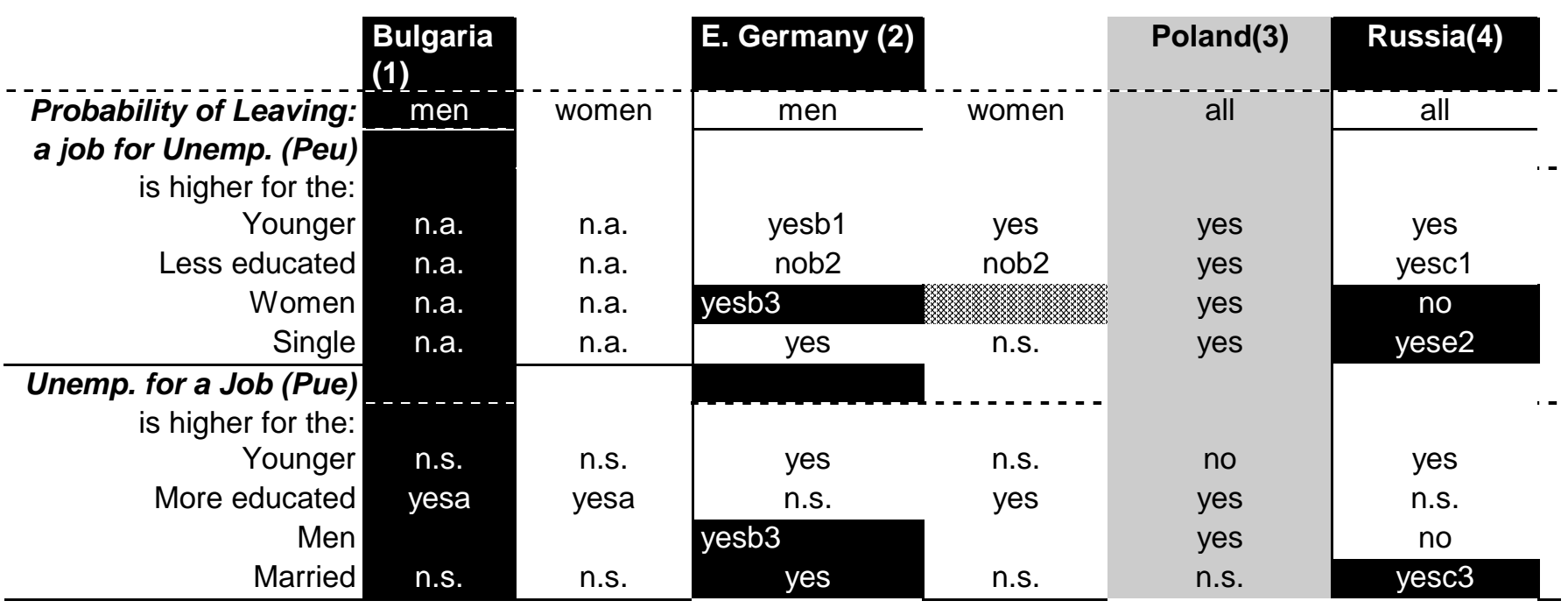

Note: ' n.s.' means not significant; 'n.a.' means not available. Findings are based on logit analysis and, except where noted, data from national Labor Force Survey data.

Sources:
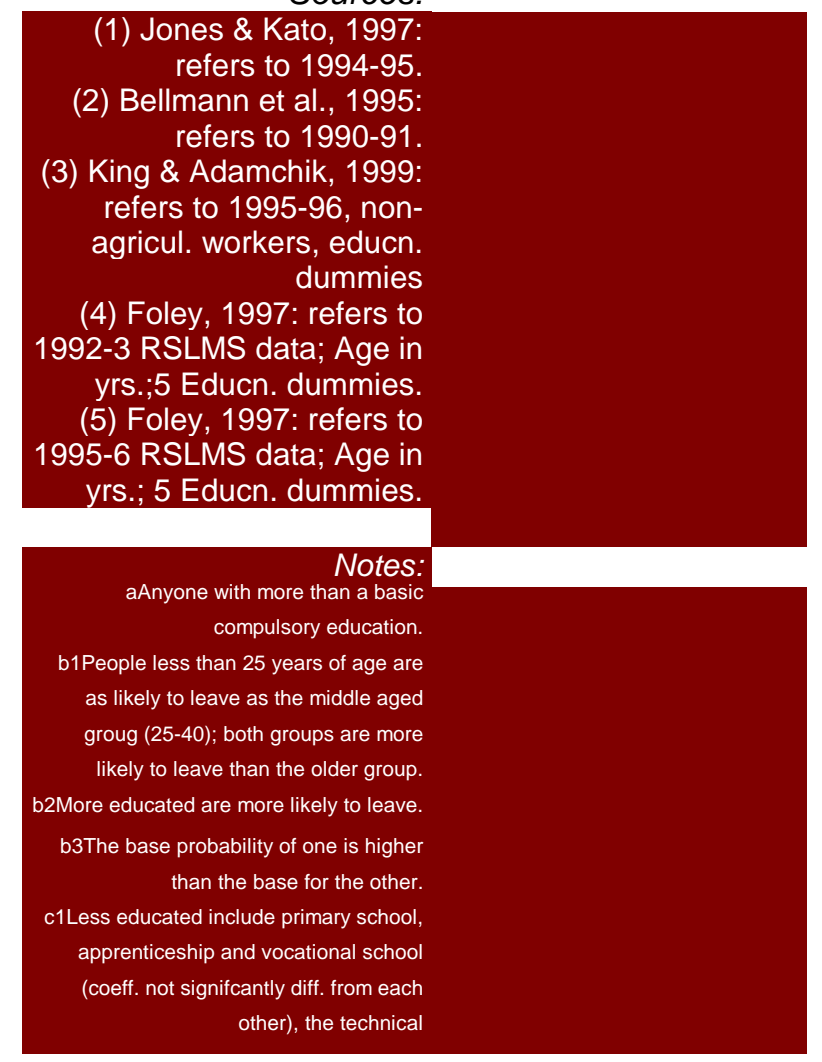
and university levels were

significantly different from

elementary and from each

c2 Not in general. However, the

interaction term for married women shows

they tend to exit from $\mathrm{e}$ to $\mathrm{u}$ at a higher

rate than single men in 1992-93.

The coefficient on this

interaction term was not

significant in 1995-96.
c3Married men are more likely to leave

than single men and married women are

less likely to leave than single men.

Table A1:

Means of the

Variables in the

Multinomial Logit

\begin{tabular}{|c|c|c|c|c|c|c|}
\hline & Employed & & $\begin{array}{c}\text { Unemplo } \\
\text { yed }\end{array}$ & & $\begin{array}{l}\text { Out-of-the } \\
\text { Labor } \\
\text { Force }\end{array}$ & \\
\hline & Mean & St. Dev. & Mean & St. Dev. & Mean & St. Dev. \\
\hline \multicolumn{7}{|l|}{ Personal Characteristics: } \\
\hline Age & 39.185 & $(12.027)$ & 34.399 & $(12.751)$ & 53.335 & $(22.871)$ \\
\hline Education & 12.130 & $(2.335)$ & 11.074 & $(1.849)$ & 10.644 & $(2.042)$ \\
\hline Married men & 0.388 & $(0.487)$ & 0.179 & $(0.383)$ & 0.215 & $(0.411)$ \\
\hline Married women & 0.339 & $(0.473)$ & 0.337 & $(0.473)$ & 0.280 & $(0.449)$ \\
\hline Single women & 0.125 & $(0.330)$ & 0.225 & $(0.418)$ & 0.332 & $(0.471)$ \\
\hline Duration (in current state) & 89.783 & $(85.201)$ & 10.210 & (16.963) & n.a. & n.a. \\
\hline \multicolumn{7}{|l|}{ Sector of Job: } \\
\hline Agriculture & 0.085 & $(0.279)$ & 0.084 & $(0.277)$ & 0.036 & $(0.187)$ \\
\hline Industrya & 0.313 & $(0.464)$ & 0.254 & $(0.435)$ & 0.088 & $(0.283)$ \\
\hline Construction & 0.087 & $(0.282)$ & 0.097 & $(0.295)$ & 0.013 & $(0.112)$ \\
\hline Tradeb & 0.217 & $(0.412)$ & 0.221 & $(0.416)$ & 0.042 & $(0.200)$ \\
\hline Public Sectorc & 0.291 & $(0.454)$ & 0.167 & $(0.374)$ & 0.053 & $(0.225)$ \\
\hline Don't Know Sector & 0.006 & (0.078) & 0.177 & $(0.382)$ & 0.768 & $(0.422)$ \\
\hline \multicolumn{7}{|l|}{ Proportion deleting 'don't } \\
\hline know' & & & & & & \\
\hline Agriculture & 0.085 & $(0.280)$ & 0.102 & $(0.303)$ & 0.156 & $(0.363)$ \\
\hline Industrya & 0.315 & $(0.464)$ & 0.309 & $(0.461)$ & 0.378 & $(0.485)$ \\
\hline Construction & 0.088 & $(0.283)$ & 0.117 & $(0.322)$ & 0.055 & $(0.228)$ \\
\hline Tradeb & 0.219 & $(0.413)$ & 0.269 & $(0.444)$ & 0.180 & $(0.384)$ \\
\hline Public Sectorc & 0.293 & $(0.455)$ & 0.203 & $(0.403)$ & 0.230 & $(0.421)$ \\
\hline Adj. total (excl. don't know) & 1.000 & & 1.000 & & 1.000 & \\
\hline \multicolumn{7}{|l|}{ Demand Variables: } \\
\hline Vacancy rate & 0.017 & $(0.007)$ & 0.016 & $(0.007)$ & 0.017 & $(0.007)$ \\
\hline Y94 & 0.182 & $(0.397)$ & 0.164 & $(0.388)$ & 0.167 & $(0.394)$ \\
\hline Y95 & 0.197 & $(0.407)$ & 0.184 & $(0.375)$ & 0.192 & $(0.407)$ \\
\hline Y96 & 0.209 & $(0.409)$ & 0.169 & $(0.405)$ & 0.210 & $(0.409)$ \\
\hline
\end{tabular}



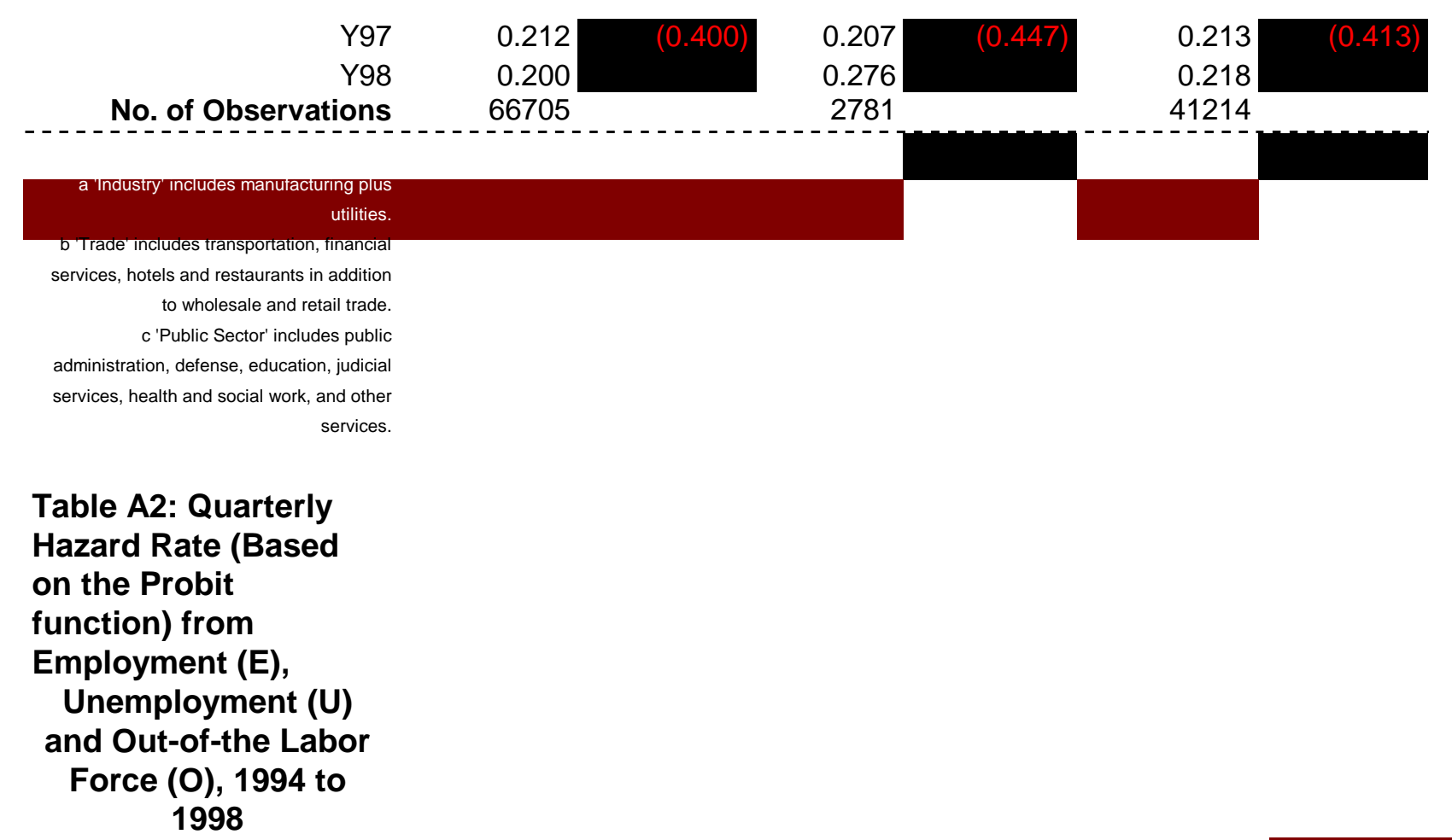

Table A2: Quarterly Hazard Rate (Based on the Probit function) from Employment (E), Unemployment (U) and Out-of-the Labor Force (0), 1994 to 1998

\begin{tabular}{|c|c|c|c|c|c|c|c|c|}
\hline \multicolumn{3}{|c|}{ Panel A } & \multicolumn{4}{|c|}{ Panel B } & \multicolumn{2}{|c|}{ Panel C } \\
\hline & Pees1 & Peej & Peu & \% & Puu & Pue & 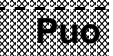 & Poo \\
\hline Base Hazard2 & 0.969 & 0.009 & 0.007 & 0.015 & 0.648 & 0.216 & 0.137 & 0.915 \\
\hline Age $=39$ & 0.970 & 0.009 & 0.007 & 0.014 & 0.645 & 0.220 & $0.134^{\circ}$ & $0 . \overline{911}$ \\
\hline Age $=33$ & 0.973 & 0.010 & 0.007 & 0.010 & 0.631 & 0.248 & 0.121 & 0.883 \\
\hline Age $=53$ & 0.955 & 0.008 & 0.005 & 0.031 & 0.668 & 0.162 & 0.169 & 0.955 \\
\hline Education 11 yrs. & 0.966 & 0.010 & 0.008 & 0.016 & 0.676 & 0.196 & 0.128 & 0.931 \\
\hline Married men & 0.984 & 0.006 & 0.004 & 0.006 & 0.554 & 0.310 & 0.136 & 0.923 \\
\hline Married women & 0.978 & 0.004 & 0.005 & 0.013 & 0.626 & 0.232 & 0.142 & 0.937 \\
\hline Single women & 0.975 & 0.005 & 0.005 & 0.015 & 0.692 & 0.188 & 0.121 & 0.921 \\
\hline Duration (in current state) & & & & & & & & \\
\hline $\begin{array}{r}\text { increased by } 10 \% \\
\text { Job (current or previous) }\end{array}$ & 0.971 & 0.008 & 0.006 & 0.014 & 0.651 & 0.212 & 0.137 & - \\
\hline & & & & & & & & \\
\hline Industry & 0.970 & 0.010 & 0.007 & 0.013 & 0.655 & 0.242 & 0.103 & 0.935 \\
\hline Construction & 0.971 & 0.010 & 0.009 & 0.010 & 0.668 & 0.257 & 0.075 & 0.881 \\
\hline Trade & 0.968 & 0.010 & 0.009 & 0.012 & 0.601 & 0.298 & 0.101 & 0.928 \\
\hline $\begin{array}{l}\text { Public Sector } \\
\text { Vacancy rate }\end{array}$ & 0.968 & 0.012 & 0.007 & 0.014 & 0.693 & 0.218 & 0.090 & 0.940 \\
\hline increased by $10 \%$ & 0.969 & 0.009 & 0.007 & 0.015 & 0.639 & 0.223 & 0.137 & 0.915 \\
\hline Y95 & 0.959 & 0.022 & 0.005 & 0.013 & 0.687 & 0.191 & 0.122 & 0.918 \\
\hline Y96 & 0.961 & 0.021 & 0.005 & 0.013 & 0.720 & 0.176 & 0.104 & 0.927 \\
\hline Y97 & 0.966 & 0.017 & 0.006 & 0.011 & 0.724 & 0.192 & 0.084 & 0.925 \\
\hline Y98 & 0.966 & 0.014 & 0.007 & 0.013 & 0.815 & 0.119 & . & 0.927 \\
\hline
\end{tabular}


function.

TPees refers to the probability of staying

employed in the same job (same employer)

from one quarter to the next. It hence excludes those who changed jobs (employers) from one quarter to the next

(Peej).

2Base razara Is tor a single man, aged 40
(avg. for $\mathrm{E}=39$, avg. for $\mathrm{O}=53$, avg. for $\mathrm{U}=11$
34), 12 years of education (avg. for $\mathrm{E}=12$,
avg. for $\mathrm{O}=11$ ), working (or
having worked) in the
agricultural sector, with
average duration in the state
(avg. for $\mathrm{E}=90$, avg. for $\mathrm{O}=$
n.a., avg. for $\mathrm{U}=10$ ),
living in a district with
average vacancy rate (0.017)
in 1994.

